NBER WORKING PAPER SERIES

\title{
EMERGING LOCAL CURRENCY BOND MARKETS
}

\author{
John D. Burger \\ Francis E. Warnock \\ Veronica Cacdac Warnock \\ Working Paper 16249 \\ http://www.nber.org/papers/w16249
NATIONAL BUREAU OF ECONOMIC RESEARCH
1050 Massachusetts Avenue
Cambridge, MA 02138

August 2010

This paper, previously circulated as "Investing in Local Currency Bond Markets", will be published in Financial Analysts Journal. The authors appreciate the help of Branimir Gruic and Denis Petre of the BIS, who provided data on the currency composition of bonds; Robert DeMason of J.P. Morgan, who provided aggregate returns data for (and guidance on) local currency bond markets; the Gemloc group at the World Bank for providing the underlying investability data; and Vahid Gholampour for superb research assistance. For helpful discussions and comments we are grateful to two anonymous referees, Pedro Elosegui, Romain Ranciere, Anderson Silva, and participants in workshops at Katholieke Universiteit Leuven, Wake Forest University and University of Crete and at Gemloc Advisory Services Conference, INFINITI Conference, and Banco de España/World Bank Conference on Financial Globalization. The views expressed herein are those of the authors and do not necessarily reflect the views of the National Bureau of Economic Research.

NBER working papers are circulated for discussion and comment purposes. They have not been peerreviewed or been subject to the review by the NBER Board of Directors that accompanies official NBER publications.

(C) 2010 by John D. Burger, Francis E. Warnock, and Veronica Cacdac Warnock. All rights reserved. Short sections of text, not to exceed two paragraphs, may be quoted without explicit permission provided that full credit, including (C) notice, is given to the source. 
Emerging Local Currency Bond Markets

John D. Burger, Francis E. Warnock, and Veronica Cacdac Warnock

NBER Working Paper No. 16249

August 2010, Revised March 2012

JEL No. F3,G01,G11,G15

\section{ABSTRACT}

We assess the development of local currency bond markets in emerging market economies (EMEs). Supported by policies and laws that helped to improve macroeconomic stability and creditor rights, many local currency EME bond markets have grown substantially over the past decade and have also provided USD-based investors with attractive returns. U.S. investors have responded by increasing their holdings of EME local currency bonds from less than $\$ 2$ billion in 2001 to over $\$ 27$ billion by end-2008. While the increase in U.S. investment spanned many EMEs, empirical tests suggest that relatively more went to those with identifiable investor-friendly institutions and policies.

John D. Burger

Loyola University Maryland 4501 N. Charles Street

Baltimore MD 21210-2699

jburger@loyola.edu

Francis E. Warnock

Darden Business School

University of Virginia

Charlottesville, VA 22906-6550

and NBER

warnockf@darden.virginia.edu
Veronica Cacdac Warnock

Darden Business School

University of Virginia

Box 6550

Charlottesville, VA 22906-6550

vwarnock@virginia.edu 


\section{Introduction}

Local currency bonds in emerging market economies (EMEs) were not a serious asset class for global investors a decade ago. About the only EME debt available to global investors at a reasonably long maturity was denominated not in the local currency but in foreign currencies such as the U.S. dollar (USD). USD-denominated EME bonds were attractive to USD-based investors, in particular because these had higher yields than U.S. bonds. This may have encouraged some EMEs to rely too heavily on foreign currency borrowing and, hence, develop severe currency mismatches between assets and liabilities. These mismatches were benign during periods of fixed or stable exchange rates, but when the local currency depreciated EME borrowers faced dramatically increased debt burdens, soon followed by defaults and bankruptcies. In such episodes_-including, among others, Mexico (1994), Thailand (1997), and Argentina (2002) — global investors' returns plummeted, even though the bonds were dollar denominated. At the core of currency mismatches and the associated currency crises was an inability to develop local currency bond markets and attract cross-border investors to participate in them. Indeed, in the 1990s local bond markets in many countries were so underdeveloped that many doubted they would ever truly materialize.

In this paper we characterize the development of EME local currency bond markets, focusing on their size, fundamental factors that enable their growth, and the returns they have produced for USDbased investors. We show that EME local currency bond markets have grown sharply over the past decade and, importantly, their growth has reduced EMEs' reliance on foreign currency debt. ${ }^{1}$ Although growth in EME local bond markets has been relatively broad-based, we find that EMEs with lower inflation volatility and stronger legal rights are better able to develop local currency bond markets. We

\footnotetext{
${ }^{1}$ We note that foreign currency debt is not problematic for those EMEs who earn substantial USD-based export revenue (e.g., commodity producers), because their assets and income streams are in dollars. For many other countries, however, dollar liabilities are not matched by dollar assets.
} 
also show that this growing asset class has provided USD-based investors with attractive returns characteristics over the past decade.

U.S. investors have responded to these favorable developments. U.S. holdings of local currency bonds increased in almost every EME in our sample, with aggregate bond holdings in EMEs increasing from less than $\$ 2$ billion in 2001 to over $\$ 27$ billion by 2008. Some EMEs received more investment than others; we find that U.S. bond portfolios are tilted toward markets that provide more potential diversification benefits (i.e., in markets that have a lower correlation with U.S. bonds) and in which the expected mean and skewness of returns are more positive. We also find one other fundamental factor matters: Countries with investor-friendly institutions and policies-specifically, fewer capital controls, greater market liquidity and efficiency, stronger regulatory quality and creditor rights, better market infrastructure, lower taxation, and a larger local institutional investor base — attract more U.S. investment.

Our work suggests a handful of fundamental factors that investors should watch as they assess EME local currency bond markets going forward. On the supply side, investors should track the evolution of legal rights for creditors. Creditor rights remain quite limited in many of the largest EMEs; improvement on this front will support additional expansion in EME bond markets, whereas any backsliding will decrease investor demand. Investors should also be mindful of the recent surge in inflation across EMEs, which could jeopardize the progress in local bond market development. If the recent increase in inflation is contained, that would be supportive of further growth in these markets and could signal a continuation of the decade-long attractive returns. On the other hand, if the hard-earned macroeconomic stability is lost and EMEs move into a more volatile, high inflation environment, both local and global investors will shun these markets. Finally, cross-border investors should also keep an 
eye on the investability measures that we show are linked to increased U.S. investor holdings of local currency bonds.

Our contributions are as follows. We present updated analysis of local currency bond market development and returns in those markets; both of these are more important than one might think, as this is a relatively new asset class about which little is understood. Now that longer time series of local currency bond returns data are available, we are able to extend and update the work of Burger and Warnock (2007) to dig more deeply into the roles of expected mean, variance, and skewness of returns in attracting (or deterring) global investors. ${ }^{2}$ Finally, we show, using an investability measure tailormade for international bond investment, the tangible steps countries could make in order to attract more global investment.

The paper proceeds as follows. In Section 2 we describe and analyze the development of EME local currency bond markets. Section 3 presents information on the returns characteristics of local currency bond markets. In Section 4 we analyze U.S. participation in local bond markets. Section 5 concludes. All data are described in some detail in the Data Appendix.

\section{The Development of EME Local Currency Bond Markets}

In this section we present information on the size of EME local currency bond markets, assess fundamental factors that enable some EME markets to be larger than others, and discuss potential warning signs.

\subsection{The Size of EME Local Currency Bond Markets}

\footnotetext{
${ }^{2}$ Analyses of cross-border bond investment also appear in Lane (2006) and Fidora, Fratzscher, and Thimann (2007), although their datasets cannot identify the currency denomination of the bonds. Burger and Warnock (2007) did not have access to true local currency bond returns for many EMEs and instead relied on estimates from USD-denominated bonds combined with currency movements.
} 
A decade ago EME local currency markets were small and irrelevant to international investors, and cross-border investment in EME bonds was limited almost exclusively to USD-denominated securities. Many doubted that local bond markets in EMEs would ever develop. One aspect of this thinking is the "original sin" hypothesis, which, in its strongest form, suggests that EMEs would forever have small, inconsequential bond markets. ${ }^{3}$ The proposition is that small countries have an innate condition that precludes the development of a local bond market, no matter how hard they try, no matter which policies they put in place, and no matter which institutions they develop.

As global investors know, the past decade has seen a strong rejection of the "original sin" hypothesis, as a wide range of EMEs have indeed been able to grow their local currency bond markets. Table 1 puts EME bond markets in a global perspective. ${ }^{4}$ Yes, the vast majority of local currency bonds — bonds denominated in the issuer's currency—-were issued by advanced economies (AEs). As of end-2008, AEs made up $\$ 56.5$ trillion of the $\$ 60$ trillion global local currency bond market. But from 2001 to 2008 EME local currency bond markets have grown both in dollar terms (from $\$ 1.6$ trillion to \$3.4 trillion) and relative to GDP (from 19\% to 23\%). Importantly, EME bond markets have grown to the extent that EMEs are now much less reliant on foreign-currency-denominated bonds that result in currency mismatches and increased susceptibility to depreciation-related crises. Foreign currency bonds were $30 \%$ of EMEs' outstanding bonds in 2001 , but shrank to only $15 \%$ of outstanding by $2008 .^{5}$

\footnotetext{
${ }^{3}$ On the original sin hypothesis, see Eichengreen and Hausmann $(1999,2005)$, among others. The view has since evolved to the extent that it is now focused on its much narrower form, the unlikelihood of emerging market currencies becoming truly international.

${ }^{4}$ As detailed in the Data Appendix, we include bonds by all domestic issuers, both government and private. Note that an important question is how much of the outstanding bonds in Table 1 is freely traded and available to investors. While data on float is now widely available for equity markets, we know of no such data for a broad range of bond markets. For some countries, such as Japan, estimates exist of "net" bonds outstanding, which excludes government agencies' holdings of government bonds, but according to BIS such adjustments are not available for most countries. Indeed, JPMorgan's GBI and GBI-EM indices are market capitalization weighted, not adjusted for float. So for now we can only say that float (or "net") as a percent of outstanding bonds likely varies greatly across countries.

${ }^{5}$ The 2001 figure for the dollar amount of outstanding EME local currency bonds is from Burger and Warnock (2006). We also note (but do not tabulate) that equity market capitalization as a percent of GDP has also risen substantially in many EMEs. Based on World Bank's Financial Structures database, 1990s annual averages and 2008 values for selected countries
} 


\subsection{Why Are Some EME Bond Markets Larger Than Others? Some Fundamental Factors}

The development of EME local currency bond markets is impressive. But EMEs are not equal in their ability to develop their bond markets. Why do some EMEs have larger local currency bond markets than others? Were "original sin" to hold, the answer would be just that some countries are naturally larger than others. Nothing, other than sheer country size, would distinguish one economy from another, and the bond markets of smaller economies would forever be inconsequential. But the original sin hypothesis is not borne out in the real world. Burger and Warnock (2006) use end-2001 bond market data to show that countries can (and have) put in place institutions and policies that foster the development of debt markets. Countries with better historical inflation performance (an outcome of creditor-friendly policies) have more developed local bond markets, both private and government, and rely less on foreign-currency-denominated bonds. Moreover, creditor-friendly laws matter; stronger rule of law is associated with deeper local bond markets, while countries with better creditor rights are able to issue a higher share of bonds in their local currency. ${ }^{6}$

Other studies that corroborate the spirit of the Burger and Warnock (2006) results include La Porta, Lopez-de-Silanes, Shleifer, and Vishny (1997), Claessens, Klingebiel, and Schmukler (2007), Jeanne and Guscina (2006), Eichengreen and Luengnaruemitchai (2006), and Mehl and Reynaud (2005). Claessens et al. (2007) finds that government bond markets are larger in large economies with deeper domestic financial systems, low inflation, larger fiscal deficits, stronger legal origin, and greater capital account openness. Eichengreen and Luengnaruemitchai (2006) find that larger country size, stronger institutions, less volatile exchange rates, and more competitive banking sectors tend to be positively associated with bond market capitalization. There are at least two caveats to the list of possible 
determinants of bond market development. As shown in Burger and Warnock (2006), the fiscal balance result applies to government bond markets (larger fiscal deficits imply, all else equal, more government borrowing and hence larger government bond markets) but not to private bond markets, and bond markets and banking systems share some fundamental factors.

We assess the size of local currency bond markets as of 2008. As in previous studies, EMEs with lower inflation volatility and stronger legal rights have more developed local bond markets (Figure 1). ${ }^{7}$ Macroeconomic stability (evident by low inflation volatility) and strong creditor rights enable many positive developments in EMEs, including the development of their bond markets. For example, over the past decade some countries with historically high and volatile inflation (e.g. Mexico, Brazil) have made the necessary macroeconomic policy adjustments to bring inflation under control and, in general, the local currency bond markets in these countries have grown and have enabled a reduced reliance on foreign currency debt. Other EMEs, including Russia, Argentina, and Pakistan, have had less success bringing inflation under control and as a result continue to have less developed and less attractive local currency bond markets. Going forward, global investors can differentiate among not-yet-investable frontier markets by examining their performance on macroeconomic stability and creditor rights.

Figure 1 provides some guidance for the future. For example, three countries - Colombia, Peru, and Croatia — score far better on both macroeconomic stability and legal rights than the size of their bond markets suggests; those bond markets may well be poised for growth. In contrast, Brazil's bond market is close to its predicted size, meaning that macroeconomic stability and creditor rights should improve before the market grows much more. For example, our estimates suggest that if Brazil were able to strengthen creditor rights to be on par with those in Czech Republic (an increase in its legal rights index from 3 to 7), Brazil's local currency bond market could increase by approximately $15 \%$ of

\footnotetext{
${ }^{7}$ In the top graph of Figure 1 we omit three outliers, countries with exceedingly high inflation volatility (Pakistan, Venezuela, and Argentina). In an unreported, very small sample regression (with 19 EME observations), inflation volatility and legal rights are both significantly related to local currency bond market development.
} 
GDP, essentially doubling in size. Significant growth in Brazil's market that is not accompanied by improvements in creditor rights and macroeconomic stability should be viewed with caution.

\subsection{Potential Warning Signs}

Information in Tables 1 and 2 not only aids the evaluation of bond market development, but also sheds light on sources of potential instability. In the past, one source of instability has been currency mismatches, but recently we see improvements in many countries. For example, in Latin America about half of all bonds were denominated in foreign currency in 2001, leaving the region highly susceptible to depreciation-related turbulence. But by 2008 local currency bond markets had developed to the extent that only 28 percent of outstanding bonds were denominated in a foreign currency. While we do not have information on the currency composition of these countries' assets, for most (except, perhaps, major commodities producers) it can be assumed that assets and income flows are primarily denominated in the local currency. ${ }^{8}$ With reduced reliance on foreign currency borrowing alleviating EMEs' historical problem with currency mismatches, investors should see a reduced likelihood and severity of future currency crises.

Not all developments in bond markets have been benign. In local currency bond markets, investors should be wary of unsustainable growth and currency mismatches. Especially among AEs, some bond markets grew too fast. Ireland's euro-denominated bonds, for example, grew tenfold in just 7 years, from $46 \%$ of GDP in 2001 to $336 \%$ by 2008 . We do not define exactly what is unsustainable as opposed to sustainable but robust growth. But a tenfold increase in a short time period has proven to be unsustainable, with questions of insolvency now ubiquitous in Ireland. Iceland is another example.

\footnotetext{
${ }^{8}$ It is true that some emerging markets are commodity producers who earn substantial USD-based export revenue. For them, dollar liabilities are not problematic, as they match the currency composition of assets. For many other countries, however, dollar liabilities are indeed a mismatch. For detail on this point, as well as measures of aggregate currency mismatches, see Goldstein and Turner (2004), and for an application to Jamaica and Trinidad and Tobago see Burger, Rebucci, Warnock, and Warnock (2010).
} 
Iceland's local currency bonds grew from $91 \%$ of GDP in 2001 to $396 \%$ by 2006 and, at the same time, it had a significant currency mismatch with $40 \%$ of its bonds being denominated in foreign currency. Amid the 2008 depreciation, crisis and defaults, its bond market shrunk to 104\% of GDP (and the currency mismatch has not improved). While EME bond markets have fared better the past decade, investors should be wary of unsustainable growth and any developing currency mismatches.

Another concern is that when countries alleviate one mismatch (e.g., currency), another mismatch (e.g., maturity) is exacerbated. But the reduced reliance on foreign currency borrowing has not been replaced by a greater reliance on short-term borrowing (Table 2). Average local currency bond maturities have generally increased over the past decade, with impressive lengthening in Latin America. We find no evidence that currency mismatches have been replaced by maturity mismatches.

Finally, high and volatile inflation smothers bond markets (and borrowing and lending in general), so the recent surge in inflation in many EMEs (and all of the BRICs) merits close attention. If this increase in inflation is contained and proves to be short-lived, local currency bond markets will not be adversely affected. But if the recent spike turns into persistently high and volatile inflation, the progress in EME local currency bond markets could quickly reverse.

\section{Returns Characteristics of EME Local Currency Bonds}

EME local currency bond markets are now sizeable and, while potential concerns remain, the policies and laws implemented in many countries should support further development. But what type of returns have these markets offered USD-based investors?

Over the period from January 2002 to May 2011, local currency EME bonds provided attractive returns (Table 3). ${ }^{9}$ Local currency EME bonds provided strong monthly mean returns, whether the

\footnotetext{
${ }^{9}$ All returns data in this paper are of local currency bonds and are from the perspective of a U.S.-resident investor (i.e., translated back into U.S. dollars). See Data Appendix for more information. Burger and Warnock (2007) studied returns
} 
currency risk was unhedged (1.01\%) or hedged $(0.46 \%)$. The volatility on unhedged EME local bonds was high, as expected; currencies are more volatile than most assets, so the USD returns on local currency EME bonds are also volatile. The skewness on local currency EME bonds was moderate, and even positive for hedged returns. EME bonds, especially when unhedged, provided substantial diversification benefits to USD-based investors, as evident by the low correlation with U.S. bond returns.

For comparison we also present returns characteristics for other asset classes. Compared to nonUS AE bonds, EME bonds dominate along a number of dimensions. EME mean returns were higher, with comparable volatility, moderate skewness, and offered significant diversification benefits (that is, they had a lower correlation with U.S. bond returns). Perhaps a more appropriate benchmark for EME bonds would be US corporate bonds or EME equities. Compared to US corporate bonds, unhedged EME bonds provided higher returns but also higher volatility. Relative to EME equities, EME local bonds provided lower returns and dramatically lower volatility. Finally we note that EMBI returns (i.e., those on dollar-denominated EME bonds) have been higher than hedged local currency EME bonds, but with much higher volatility and very negative skewness (indicating a few too many really bad outcomes).

The bottom panel of Table 3 displays data for the crisis period from August 2007 to May 2011. Even during the crisis local currency EME bond returns exhibited favorable characteristics. As expected the variance of returns increased across all asset classes during the financial crisis. During the crisis period EME local currency bond returns were comparable to non-US AE bonds, but the low correlation with US bonds implied greater diversification benefits. US corporate bonds fared somewhat better than EME local bonds during the crisis with moderately higher returns and significantly lower variance. And

characteristics from 1998 to 2001. Two features stood out in that study. First, over that sample period, for AE bonds, hedged returns were much less volatile than unhedged returns, but unhedged bonds provided a more attractive skewness profile. Second, compared to AE bond markets, emerging economy bond markets were much more volatile and exhibited significantly more negative skewness. Note that for local currency emerging market bond returns, off-the-shelf indices did not exist, so they constructed EME returns using EMBI/JACI and currency returns. In contrast, in this paper we can rely on time series of local currency EME bonds that are now available. 
EME local bonds provided superior returns and dramatically lower volatility when compared to EME equities.

We caution that the returns characteristics for EME bonds portrayed in Table 3 are likely more favorable than those in previous periods. For one, the USD depreciated against many currencies in our sample period, adding to unhedged local currency bond returns translated back into dollars. Were the dollar to appreciate materially, EME bond returns would suffer. Second, in the 1990s, although systematic local currency EME bond returns were not available, returns were highly volatile (as inflation and exchange rates were volatile) and negatively skewed (as spikes in bond yields and, hence, negative returns on the underlying bonds, coincided with financial flight that depreciated the currency). In AE bond markets, prior to the eurozone debt crisis, periods of negative bond returns often coincided with currency appreciations, eliminating the occasional extremely bad outcome for international investors. In contrast, in EMEs the bad outcome of negative bond returns was often exacerbated by a plummeting currency. The good news for the global fixed income investor is that in the past decade the improved policy stability achieved by a number of EMEs has been helpful in alleviating the joint bad outcomes of losses on bonds and a depreciating currency.

Efficient frontiers help summarize lessons from returns data. In Figure 2 we generate three allbonds efficient frontiers to illustrate the risk-return tradeoffs facing a U.S.-resident fixed income investor. Each frontier includes a range of bond portfolios varying from 100\% U.S. bonds to $100 \%$ foreign bonds (labeled 'ROW'). The figure includes three measures of the rest-of-world (ROW) portfolio: (1) an unhedged portfolio of 80 percent AE and 20 percent EME bonds, (2) a hedged portfolio of 80 percent $\mathrm{AE}$ and $20 \%$ percent EME bonds, and (3) a 50-50 combination of (1) and (2).

We draw a few important lessons from the frontiers. First, the attractiveness of local currency bonds for cross-border investors can be impeded by significant currency risk. From the perspective of a 
U.S. investor, adding unhedged foreign bonds significantly increases portfolio risk. In the January 2002 to May 2011 period, the added risk happened to be compensated by strong returns (because of the falling U.S. dollar), but in earlier periods the additional risk was accompanied by substantially lower returns (because the dollar was appreciating). ${ }^{10}$ The figure also indicates the gains to diversification from adding hedged foreign bonds, which over this period (and earlier periods) reduced portfolio risk without much deterioration of returns. A mix of hedged and unhedged bonds provided a particularly attractive riskreturn tradeoff over this period, suggesting that, while choosing not to hedge the currency risk makes a cross-border investment in EME local currency bonds largely a currency play (with some yield) in an instrument that might not be as liquid as desired, global investors will likely prefer bonds in countries where they can decide whether or not to hedge the currency risk.

Figure 3 broadens the set of assets to all included in Table 3. We select weights for each asset class from 2006, roughly the midpoint of the January 2002 to May 2011 period. Weights for the U.S. portion are based on 2006 estimates from the Federal Reserve's Flow of Funds accounts: 62\% equities, $38 \%$ bonds, of which $43 \%$ government and $57 \%$ corporate. For the rest-of-world (ROW) portion, weights, which come from Treasury Department surveys as described later in Table 4 and also in the Data Appendix, are 77\% equity (of which 79\% AE and 21\% EME) and 23\% bond (89\% AE, 9\% USDdenominated EME, 2\% local currency EME). As in Figure 2, we allow for bond portfolios to be unhedged or hedged against currency fluctuations. Over this period, efficient frontiers for the broader portfolio are upward sloping; more return was accompanied by more risk.

In the bottom graph of Figure 3 we ramp up the local currency EME bond weight by increasing the overall bond weight in the ROW portfolio to 59.4\% (from 23\%) and the local currency EME portion

\footnotetext{
${ }^{10}$ The hedged frontier in Figure 2 is very similar to the hedged frontier in Burger and Warnock (2007) for periods ending in 2001, but the unhedged frontier from that earlier period was downward sloping (ROW bonds brought with them increased risk and less reward). In an even earlier period (1977-1990), Levich and Thomas (1993) find that currency volatility more than outweighed the increased returns and the optimal (ex post) unhedged bond portfolio would have been composed mainly of U.S. bonds.
} 
of that to $20 \%$ (from $2 \%$ ). ${ }^{11}$ The efficient frontiers of this portfolio, with much greater weight on local currency EME bonds, represent superior opportunities relative to those with actual portfolio weights. The ramped up EME bond portfolios generate higher returns for any given level of risk.

In summary, local currency bonds have offered attractive returns characteristics. For a USDbased investor, unhedged local currency EME bonds are largely a currency play against the USD (with some yield), so mean returns depend importantly on how EME currencies perform against the USD. Hedged returns are more stable, but offer somewhat less diversification benefits.

\section{U.S. Participation in Local Currency Bond Markets}

In this section we present data on the extent of U.S. investment in EME local currency bond markets and analyze factors that attract U.S. investor participation. The U.S. investment data come from mandatory, comprehensive benchmark surveys that form the basis for official U.S. data. ${ }^{12}$

\subsection{The Extent of U.S. Holdings of Local Currency Bonds}

Analysis of the 2001 benchmark survey of U.S. investment revealed an overwhelming preference for bonds denominated in U.S. dollars, with near zero participation in EME local currency bond markets and a particular aversion to the most volatile markets (Burger and Warnock 2007). Since 2001 there have been dramatic changes in local currency bond markets, as highlighted in the previous sections. EMEs have greatly reduced their reliance on foreign currency debt and focused efforts on building local currency bond markets, which have had attractive returns characteristics.

\footnotetext{
${ }^{11}$ The 59.4\% is the actual bond weight on foreigners' U.S. portfolios (see Curcuru, Dvorak, and Warnock 2010).

${ }^{12}$ Ideally, we would study all foreign investors' positions in local currency bonds, but unfortunately such a study is not currently possible. One broad multilateral database does exist—namely the IMF's Coordinated Portfolio Investment Survey (CPIS) data set - but it does not include vital information about the currency denomination of bond holdings. Papers on cross-border bond investment that utilize CPIS data include Lane (2006) and Fidora, Fratzscher, and Thimann (2007). With our focus on local currency bonds, we cannot use CPIS data.
} 
U.S. investors have responded to these developments. Subsequent benchmark surveys reveal a striking increase in investment in EME local bonds, from \$1.7 billion in 2001 to $\$ 27.5$ billion in 2008 (Table 4), with increased investment spreading across a wide range of EMEs. An examination of portfolio weights also shows a shift toward EMEs. The weight of EMEs in U.S. investors' local currency bond portfolio has steadily increased, from 0.01 percent of the portfolio (which includes the U.S. bond market) in 2001 to 0.13 percent in 2006 and 0.16 percent in 2008. U.S. participation increased somewhat in Emerging Asia and sharply in Latin America. ${ }^{13}$ The EME weights might seem small (because 98 percent of the bonds held by U.S. investors are U.S. bonds), but U.S. investors' EME holdings, only 1.1 percent of their AE holdings in 2001, rose to 10.3 percent of AE holdings by 2008 . However scaled, U.S. investment in EME local bonds has increased the past decade.

\subsection{Why Are Some EMEs More Attractive to U.S. Investors Than Others?}

U.S. investment in many EME local bond markets is now substantial. But some EMEs receive more U.S. investment than others. We assess some fundamental factors behind the amount of U.S. investment a particular EME bond market receives using a simple model of portfolio allocation that encompasses two features of international bond markets: barriers to international investment and returns that exhibit higher moments. We then use the model to inform cross-sectional regressions of the extent to which U.S. investors' portfolio weights deviate from benchmark (market) weights.

The model is as follows. Following the work of Kraus and Litzenberger (1976), de Athayde and Flores (2004), Harvey, Liechty, Liechty, and Muller (2010), and Burger and Warnock (2007), we allow for the fact that asset returns exhibit higher moments and that investors with nonincreasing absolute risk

\footnotetext{
${ }^{13}$ The portfolio weight of U.S. bonds fell slightly from 98.76 to 98.25 percent from 2001 to 2008 . AEs have increased modestly from 1.23 percent of U.S. investors' bond portfolios in 2001 to 1.64 percent in 2006 before falling to 1.59 percent in 2008 .
} 
aversion should care about skewness in addition to mean and variance. ${ }^{14}$ The analytics are rather complicated - see Harvey et al. (2010) and de Athayde and Flores (2004), who note that feasible solutions can be calculated in most cases_-but take the general form:

$$
\omega=f\left(\stackrel{+}{x}, \bar{V}_{x}, \stackrel{+}{S}_{x}\right)
$$

where the signs above the arguments indicate that portfolio weights $(\omega)$ should be higher on countries whose bonds add to the portfolio's expected returns $(x)$ and expected skewness $\left(S_{x}\right)$ and reduce the portfolio's variance $\left(V_{x}\right)$. In an international setting, we also control for barriers to international investment, such as restrictions on the repatriation of investment income, and potential diversification benefits. Direct barriers to international investment, barriers, can be modeled by assuming that they impose a cost that varies across countries and reduces investors' expected returns. ${ }^{15}$ As a proxy for potential diversification benefits, we include the correlation of each country's bond returns with U.S. bond returns, corr $_{i}$, calculated over a 36-month period.

Thus, our empirical exercise in this section assesses the extent to which barriers to international investment, potential diversification benefits, and expected mean, variance, and skewness of returns affect cross-country differences in U.S. portfolio allocations. Specifically, we assess relationships of the following form:

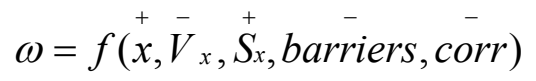

\footnotetext{
${ }^{14}$ As Kraus and Litzenberger (1976) note, while one could include fourth and higher moments, we lack compelling behavioristic arguments for investor attitudes for those moments.

${ }^{15}$ For portfolio allocation models with barriers to international investment, see Black (1974), Stulz (1981), and Cooper and Kaplanis (1986).
} 
While computing the last factor, corr, is straightforward, measures of other variables (expected mean, variance, and skewness of returns and barriers to international investment) require some discussion.

\subsubsection{Expected Mean, Variance, and Skewness of Returns}

Off-the-shelf time series data of the expected mean, variance, and skewness of local currency bond returns do not exist, so we construct them. We assume cross-border investors have a one-year horizon and, thus, estimate one-year ahead expectations. Because lagged realizations of mean, variance, and skewness will likely inform expectations (at least to some extent), to form expectations we use the dynamic panel-data model of Blundell and Bond (1998)

$$
y_{i t}=\sum_{j=1}^{p} \alpha_{j} y_{i, t-j}+x_{i t} \beta_{1}+w_{i t} \beta_{2}+v_{i}+\varepsilon_{i t}
$$

for $i=\{1, \ldots, \mathrm{N}\}$ and $t=\left\{1, \ldots, \mathrm{T}_{i}\right\}$, where $y_{i t}$ is one-year ahead mean, variance, or skewness of country $i$ 's USD returns, $x_{i t}$ are strictly exogenous explanatory variables, $w_{i t}$ are predetermined explanatory variables, and $v_{i}$ are country-level panel effects. Using annual data, we include in these first stage regressions lags of the dependent variables as well as exogenous or predetermined variables such as bond yields, inflation, and current account balances.

Regression results are shown in Table 5. We find that expected mean returns are higher in countries with lower lagged mean returns, higher yields, more positive current account balances, and lower real GDP growth. ${ }^{16}$ For expected skewness and expected volatility, we find these are best estimated with their own lags. Importantly, the correlations between predicted and realized mean,

\footnotetext{
${ }^{16}$ Most of the estimated coefficient signs are as expected. For GDP growth a negative coefficient is intuitive given that a slowdown in current economic activity frequently generates falling interest rates and thus positive bond returns. The negative coefficient on lagged returns suggests that a year of high returns is often followed by a year of lower returns.
} 
variance, and skewness (shown in the last row of Table 5) are reasonably high and statistically significant, suggesting that our regressions provide suitable estimates of the expected mean, variance, and skewness of international bond returns.

\subsubsection{Barriers to International Investment in Bonds}

For barriers to international investment, we use the inverse, an openness measure called Investability, which was custom-made for cross-border investment in local currency bonds. CRISIL $(2008,2009)$ provides the bulk of data for Investability. Somewhat similar to the country-level investability measures for equities devised in Edison and Warnock (2003), CRISIL (in cooperation with the World Bank) created investability scores for local currency bond markets in a range of EMEs. In the CRISIL data, there are six broad components to investability: capital controls, market liquidity and efficiency, regulatory quality and creditor rights, market infrastructure, taxation on bonds, and the size of the local institutional investor base. Capital controls data are from AREAER (2007) and countries are scored on three indicators that are particularly relevant from the perspective of investment in local currency bond market, namely, access to securities market, access to domestic money market, and access to the derivatives market. The market liquidity and efficiency measure is formed by combining four variables: secondary market turnover ratio, bid-ask spread, existence of a yield curve, and existence of centralized bond price data. Regulatory quality and creditor rights are taken from the World Bank's Regulatory Quality Index (Worldwide Governance Indicators) and Creditor Rights Index (Doing Business database). Market infrastructure indicators cover efficiency of clearing and settlement systems, safety and soundness of safekeeping arrangements, and efficiency of asset servicing. Effective tax rates are from the perspective of a Luxembourg-based institutional investor. Finally, investor base is the size of institutional investor base (pension and mutual funds) as a share of GDP. For complete details, see CRISIL (2008, 2009). 
The CRISIL investability data for 2006 are available for the 20 Gemloc countries; coverage was expanded to 34 countries in $2008 .{ }^{17}$ In addition, we added roughly 20 AEs by creating similar indices. For readily available data, such as capital controls and the components of regulatory quality and creditor rights, this task is straightforward and we can confidently form scores. For items for which we are unable to gather data, such as market infrastructure, we assume the maximum score for AEs, which we argue is a plausible approximation. ${ }^{18}$

\subsubsection{Explaining U.S. Investment}

We run Tobit regressions of the following form:

$$
\frac{\omega_{i, u s}}{\omega_{i, m}}=\alpha_{0}+\alpha_{1} \text { Investability }_{i}+\alpha_{2} x_{i}+\alpha_{3} V_{i}+\alpha_{4} S_{i}+\alpha_{5} \operatorname{corr}_{i}+\varepsilon_{i}
$$

where $\omega_{i, \text { us }} / \omega_{i, m}$ is the weight of country $i$ in the U.S. bond portfolio $\left(\omega_{i, u s}\right)$ relative to its weight in the world bond market portfolio $\left(\omega_{i, m}\right)$; Investability $y_{i}$ is a measure of investability; $x_{i}, V_{i}$, and $S_{i}$ are the expected mean, variance, and skewness of returns as of the end of the year; and corr $_{i}$ is the 3 -year correlation of the bond returns of country $i$ with U.S. bond returns.

We make one minor transformation before estimation. Note that $\omega_{i, \text { us }} / \omega_{i, m}$ is a constant multiplied by the percentage of a country's bond market held by U.S. investors. Let $\sum_{i=1}^{N} H_{i}^{U S}$ be total U.S. holdings of all countries' bonds and $\sum_{i=1}^{N} M C a p_{i}$ be the size of all countries' bond markets. At a

\footnotetext{
${ }^{17}$ The World Bank's Global Emerging Markets Local Currency Bond (Gemloc) Program supports the development of local currency bond markets in EMEs.

${ }^{18}$ We deviated from this in creating investability data for four additional countries: Greece (which we assumed scored slightly better than Turkey), Portugal (average of Greece and Spain), Czech Republic (average of Poland and Slovakia), and Korea (assumed to score similar to Chile). If we omit these four observations, results are nearly identical to our reported results.
} 
point in time the expression $\sum_{i=1}^{N} H_{i}^{U S} / \sum_{i=1}^{N} M C_{a p}$ is a constant (call it $X$ ) equal to the relative size of U.S. investors (i.e., the share of U.S. holdings relative to the world market). Then $\omega_{i, \text { us }} / \omega_{i, m}$ can be written as

$$
\frac{\omega_{i, U S}}{\omega_{i . m}}=\frac{H_{i}^{U S} / M C_{a p}}{X}
$$

In a cross-sectional regression, $X$ becomes part of the constant term. Variation in $\omega_{i, \text { us }} / \omega_{i, m}$ is given by variation in the percentage of a country's bond market held by U.S. investors $j$, which we denote by $v_{i}^{U S}$. Define $v_{i}^{U S}$ as

$v_{i}^{U S}=H_{i}^{U S} / M_{C a p}$

For purely expositional reasons, in our regressions we will use $v_{i}^{U S}$, which at a point in time is observationally equivalent to $\omega_{i, \text { us }} / \omega_{i, m}$. Our baseline specification is

$$
v_{i}^{U S}=\alpha_{0}+\alpha_{1} \text { Investability }_{i}+\alpha_{2} x_{i}+\alpha_{3} V_{i}+\alpha_{4} S_{i}+\alpha_{5} \text { corr }_{i}+\varepsilon_{i}
$$

Empirical results are presented in Table 6. The dependent variable in each regression is $v_{i}^{U S}$ as of end2006 or end-2008. ${ }^{19}$ The results for both years indicate that countries with higher scores on the aggregate investability index and, separately, most of the individual subindexes are able to attract

\footnotetext{
${ }^{19}$ Colombia is excluded from this analysis (and hereafter) because, as can be inferred from Table 4, it represents an outlier in terms of the extremely large percentage of Colombian peso-denominated bonds held by U.S. investors.
} 
significantly more U.S. investment into local currency bond markets. The coefficients on the investability index are also economically significant. For example using the 2008 coefficients we find that if Argentina were able to increase its aggregate investability (0.51) to the level of Mexico (0.69), U.S. investors would increase their holdings of Argentine peso bonds by approximately one percent of the existing market, a quite substantial amount given that U.S. investors held $0.6 \%$ of the market as of end-2008.

In addition to the significance of the investability indexes, we find the expected mean and skewness of returns are borderline significant in most of the end-2006 regressions, which we interpret as modest evidence that U.S. investors had larger (relative) positions in countries in which they expected higher mean returns and more positive skewness. The 2008 regressions reveal some evidence that U.S. investment is greater in countries that offer more potential diversification benefits (i.e., some coefficients on the correlation variable are negative and significant).

It is reasonable to investigate what drove portfolio reallocations over the 2006-2008 period. With so few countries, however, a formal analysis would quickly run into problems with degrees of freedom. Cursory analysis of the changes in portfolio weights from 2006 to 2008 (not shown) suggests that U.S. investors moved toward markets in which they had smaller initial (2006) positions and that had higher expected returns as of end-2006. As Table 4 suggests, many of the increases in U.S. investment occurred in EMEs.

The above analysis used unhedged returns. If instead hedged returns are used, the reduced variation across countries and the small sample renders the explanatory variables insignificant. Importantly, the diversification benefits through low correlations with U.S. bonds evident in unhedged returns are less pronounced in hedged returns, removing one important determinant of holdings. More generally, it could be if investors hedge the currency risk then returns are more related to broader global 
risks rather than country-specific returns characteristics. Regardless, the relationship between EMEs' investability and U.S. investor positions is positive and statistically significant (Figure 4).

In sum, the analysis in this section shows growing participation by U.S. investors in local currency bonds in EMEs. The importance of the investability measure establishes a concrete set of policy settings and institutional factors that are linked to higher cross-border participation. ${ }^{20}$ The analysis in Figure 4 also suggests that some markets are poised for much more US participation (e.g., Turkey and Chile, both of which score well on investability but have relatively little U.S. participation) and others (such as Brazil) perhaps have more U.S. investment than their investability supports.

\section{Conclusion}

The recovery of EMEs from the string of crises in the late 1990s was remarkable in many ways, not the least of which has been the development of local currency bond markets. After suffering the consequences of currency mismatches, many EMEs have established the necessary institutional framework and pursued creditor-friendly policies in an effort to develop local bond markets. These efforts have borne fruit. In the period between 2001 and 2008 we document a substantial improvement in local currency bond market development and a reduced reliance on foreign currency denominated bonds. In fact, the most vulnerable area in 2001, Latin America, has made the most dramatic progress. Although the growth in local bond markets has been relatively broad-based, we find important differences across EMEs. EMEs with lower inflation volatility and stronger legal rights have been better able to develop local currency bond markets. Improved macroeconomic stability and institutional

\footnotetext{
${ }^{20} \mathrm{An}$ important aspect of bond market development and international investment is the availability of hedge instruments. By enabling investors to transfer risk to those more willing to bear it, the existence of derivatives markets to hedge currency and interest-rate exposure should make local bond markets more attractive to both foreign and local investors. Active derivatives markets do not exist in every country, although progress (more so with currency risk than interest-rate risk) has been made of late; see Saxena and Villar (2008). The ability to hedge currency risk is intimately related to bond market development, because without a liquid bond market and an established yield curve, derivative securities cannot be priced, and a wellfunctioning derivatives market will not develop (Carlton 1984). Future work should investigate the relationship between the existence of derivatives markets and foreign participation in local bond markets.
} 
improvements have coincided with a period of bond returns that, from the perspective of a USD-based investor, compare favorably to AE bonds and a variety of other asset classes.

U.S. investors have responded to these propitious developments, sharply increasing their holdings of EME bonds from less than $\$ 2$ billion in 2001 to over $\$ 27$ billion by 2008 . The increased investment was widespread, reaching almost every EME in our sample, with cross-border participation highest in countries where investor-friendly institutions and policies have been established.

Finally, bond market development is a positive and all else equal borrowing by issuing local currency bonds should dominate foreign-currency borrowing (except, possibly, for commodity exporters), but history is not kind to markets that grow too quickly. Moreover, we emphasize that while much of the 2000s were remarkably stable for EMEs, that period of tranquility has clearly come to an end. The global financial crisis has generated significant stress in EMEs and local currency bond markets have not been spared. Those caveats aside, EMEs have fared very well. During the recent crisis many EMEs suffered significant (albeit, for most, short-lived) currency depreciations, but reduced reliance on foreign-currency-denominated bonds meant that there were few instances of exploding foreign currency debt burdens. Further, although some reports indicate flight from local currency assets, our data show that, on average, U.S. investors maintained or even increased their positions in EMEs' local currency bond markets through the crisis. 


\section{References}

AREAER. 2007. Annual Report on Exchange Arrangements and Exchange Restrictions (Washington, DC: IMF).

Bank for International Settlements. 2007. Financial stability and local currency bond markets. CGFS Papers No. 28.

Black, Fisher. 1974. International Capital Market Equilibrium with Investment Barriers. Journal of Financial Economics 1(4): 337-352.

Blundell, Richard, and Steve Bond. 1998. Initial conditions and moment restrictions in dynamic panel data models. Journal of Econometrics 87: 115-143.

Burger, John D., Alessandro Rebucci, Francis E. Warnock, and Veronica Cacdac Warnock. 2010. External Capital Structures and Oil Price Volatility. Journal of Business, Finance and Economics in Emerging Economies 5(2): 1-37.

Burger, John D., and Francis E. Warnock. 2007. Foreign Participation in Local Currency Bond Markets. Review of Financial Economics 16(3): 291-304.

Burger, John D., and Francis E. Warnock. 2006. Local Currency Bond Markets. IMF Staff Papers 53: 115-132.

Carlton, Dennis. 1984. Future Markets: Their Purpose, Their History, Their Growth, and Their Successes and Failures. Journal of Futures Markets 4(3): 237-271.

Claessens, Stijn, Daniela Klingebiel, and Sergio Schmukler. 2007. Government Bonds in Domestic and Foreign Currency: The Role of Macroeconomic and Institutional Factors. Review of International Economics 15(2), 370-413.

Cooper, Ian, and Evi Kaplanis. 1986. Costs to Cross-border Investment and International Equity Market Equilibrium. in J. Edwards, J. Franks, C. Mayer and S. Schaefer (eds.), Recent Developments in Corporate Finance. Cambridge: Cambridge University Press.

CRISIL. 2008. Gemloc Investabilty Indicators. Manuscript.

CRISIL. 2009. Gemloc Investibility Indicators - Phase 2 extension. International Finance Corporation.

Curcuru, Stephanie E., Tomas Dvorak, and Francis E. Warnock. 2010. Decomposing the U.S. External Returns Differential. Journal of International Economics 80: 22-32.

de Athayde, Gustavo, and Renato Flores. 2004. Finding a Maximum Skewness Portfolio - A General Solution to Three-Moments Portfolio Choice. Journal of Economic Dynamics and Control 28(7): 1335-1352.

Edison, Hali and Francis E. Warnock. 2003. A simple measure of the intensity of capital controls. Journal of Empirical Finance. 10(1): 2003 pp. 81-103.

Eichengreen, Barry, and Ricardo Hausmann. 1999. Exchange rates and financial fragility. Proceedings, Federal Reserve Bank of Kansas City, pages 329-368.

Eichengreen, Barry, and Ricardo Hausmann. 2005. Other People's Money: Debt Denomination and Financial Instability in Emerging Market Economies. Chicago: University of Chicago Press. 
Eichengreen, Barry, and Pipat Luengnaruemitchai. 2006. Why Doesn't Asia Have Bigger Bond Markets? in Asian Bond Markets: Issues and Prospects (BIS Paper No. 30).

Fidora, Michele, Marcel Fratzscher, and Christian Thimann. 2007. Home Bias in Global Bond and Equity Markets: The Role of Real Exchange Rate Volatility. Journal of International Money and Finance 26: 631655.

Goldstein, Morris, and Philip Turner. 2004. Controlling Currency Mismatches in Emerging Economies. Institute for International Economics, Washington, D.C.

Griever, William, Gary Lee, and Francis E. Warnock. 2001. The U.S. system for measuring cross-border investment in securities: a primer with a discussion of recent developments. Federal Reserve Bulletin 87(10): 633-650.

Harvey, Campbell, John Liechty, Merrill Liechty, and Peter Muller. 2010. Portfolio Selection with Higher Moments. Quantitative Finance 10(5): 469-485.

Jeanne, Olivier, and Anastasia Guscina. 2006. Government Debt in Emerging Market Countries: A New Data Set. IMF Working Paper 06/98.

J.P. Morgan. 2002. JPMorgan Government Bond Indices. J.P. Morgan Portfolio Research, January 14.

J.P. Morgan. 2006. Introducing the JPMorgan Government Bond Index-Emerging Markets (GBI-EM): Index Methodology. J.P. Morgan Emerging Markets Research and Bond Index Research, January.

Kraus, Alan, and Robert Litzenberger. 1976. Skewness Preferences and the Valuation of Risk Assets. Journal of Finance 31(4): 1085-1100.

La Porta, Rafael, Florencio Lopez-de-Silanes, Andrei Shleifer, Robert Vishny. 1997. Legal Determinants of External Finance. Journal of Finance 52(3): 1131-1150.

Lane, Philip. 2006. Global Bond Portfolios and EMU. International Journal of Central Banking 2(2): 1-23.

Levich, Richard, and Lee Thomas. 1993. The Merits of Active Currency Risk Management: Evidence from International Bond Portfolios. Financial Analysts Journal 49(5): 63-70.

Mehl, Arnaud and Julien Reynaud. 2005. Domestic original sin in emerging market economies. ECB Working Paper No. 560.

Saxena, Sweta and Agustin Villar. 2008. Hedging instruments in emerging market economies. In "Financial globalisation and emerging market capital flows", BIS Papers No 44.

Stulz, Rene. 1981. On the Effects of Barriers to International Investment. Journal of Finance, 36: 923-934.

U.S. Department of the Treasury, Federal Reserve Bank of New York, and Board of Governors of the Federal Reserve System. 2002. Report on U.S. Portfolio Holdings of Foreign Securities as of December 31. 2001.

U.S. Department of the Treasury, Federal Reserve Bank of New York, and Board of Governors of the Federal Reserve System, 2007. Report on U.S. Portfolio Holdings of Foreign Securities as of December 31, 2006. 
U.S. Department of the Treasury, Federal Reserve Bank of New York, and Board of Governors of the Federal Reserve System. 2009. Report on U.S. Portfolio Holdings of Foreign Securities as of December 31, 2008. 


\section{Data Appendix}

Throughout, "bonds" refer to debt instruments with greater than one year original maturity. We focus on bonds denominated in the currency of the issuer.

\section{Bond Returns}

Our main source of returns data is country-level JPMorgan Government Bond Indexes (GBI) and JPMorgan Government Bond Indexes-Emerging Markets (GBI-EM). See J.P. Morgan $(2002,2006)$ for complete descriptions.

GBI consists of "regularly traded, fixed-rate, domestic government bonds of countries that offer opportunity to international investors. These countries have liquid government debt markets, which are stable, actively traded markets with sufficient scale, regular issuance and are freely accessible to foreign investors." The indices should be representative (span and weight the appropriate markets, instruments and issues that reflect opportunities available to international investors) and investible and replicable (include only securities in which an investor can deal at short notice and for which firm prices exist). The 13 countries in the original GBI include Australia, Belgium, Canada, Denmark, France, Germany, Italy, Japan, Netherlands, Spain, Sweden, UK, and the US.

The GBI-EM is similar to the main GBI in methodology but tracks emerging markets economies. Some of the bonds are speculative; some bond markets are not directly hedgeable. Countries in the GBI-EM include Brazil, Chile, Colombia, Czech Republic, Hungary, Indonesia, Malaysia, Mexico, Poland, Slovakia, South Africa, Thailand, and Turkey. Bonds in the countries in the narrow GBI-EM should be easy to access, with no impediments for foreign investors. A few countries with sizeable local bond markets but that have substantial restrictions on foreigners (China, India, Russia) are added to create the GBI-EM BROAD, which has 16 EMEs.

JPMorgan returns data are available for positions that are unhedged and hedged using exchange rates and forward rates from WM Company as of 4pm London time. Hedging for a few countries in the GBI-EM has not always been possible (e.g., Malaysia, Chile), so hedged returns for some EMs should be viewed as indicative but not actual. Please see Appendix E of JPMorgan (2006) for complete details.

We also include for comparison a U.S. corporate bond index, a dollar-denominated EME bond index (JPMorgan's EMBI), and three equity indices. The Dow Jones Corporate Bond Index is an equally weighted basket of 96 recently issued, readily tradable, investment-grade corporate bonds. We use the index with 5-year maturity. The equity indices are the S\&P500 (for the US), MSCI EM, and MSCI EAFE+Canada; see www.msci.com/products/indices/tools/index.html for details on the MSCI data.

\section{Bonds Outstanding}

We use two complementary sources of data on the amount of a country's outstanding local currency bonds. Both are from the Bank for International Settlements (BIS), which compiles data from multiple sources.

One data set is on "domestic debt", which the BIS defines as local currency bonds issued by locals in the local market (i.e., not placed directly abroad). Data are available in BIS Quarterly Review Table 16A (Domestic Debt Securities). Because our focus is on bonds (with original maturity longer than one year), we obtained the data underlying Table 16A to separate short term from long term.

The other data set is on "international bonds", bonds issued either in a different currency or in a different market. Certain aggregates of this are presented BIS Quarterly Review Table 14B (International Bonds and Notes by Country of Residence). For our focus we obtained the underlying data, as issuance by currency by country is not presented in the Quarterly Review.

With these two sources (and our calculations), local-currency-denominated debt is the sum of the longterm debt component of "domestic debt" and the local currency / local issuer portion of "international bonds". Our measure includes all bonds issued by all types of issuers (government and private).

\section{U.S. Bond Holdings}

Data on U.S. investors' holdings of local currency bonds is from periodic, comprehensive benchmark surveys conducted by the Treasury Department, Board of Governors of the Federal Reserve System, and the 
Federal Reserve Bank of New York. See the actual surveys, for example, Treasury Department et al. (2002, 2009) or the Griever, Lee, and Warnock (2001) primer for details. Briefly, from Griever, Lee, and Warnock (2001), the so-called "asset surveys" of U.S. holdings of foreign securities collect data from two types of reporters: U.S.resident custodians and U.S. institutional investors. Custodians are the primary source of information, typically reporting about 97 percent of total U.S. holdings of foreign long-term securities. Institutional investors, such as mutual funds, pension funds, insurance companies, endowments, and foundations, report in detail on their ownership of foreign securities only if they do not entrust the safekeeping of these securities to U.S.-resident custodians. If they do use U.S.-resident custodians, institutional investors report only the name(s) of the custodian(s) and the amount(s) entrusted (and the data are collected from the custodian, but not double counted).

Reporting on the asset surveys is mandatory, with both fines and imprisonment possible for willful failure to report. The data are collected at the security-level, greatly reducing reporting error; armed with a security identifier, a mapping to the currency of the bond and the residence of its issuer is straightforward. Reporting and the data are comprehensive, and the holdings data form the official U.S. data on international positions (for example, the number for international bonds in the Bureau of Economic Analysis's International Investment Position report is formed by aggregating the survey's security-level information).

For our purposes, we needed a split (U.S. holdings of local currency foreign bonds) not usually published in the Treasury Department reports, and so persuaded Treasury to include an 'own currency' column in the published table on holdings by country by currency (see, for example, Table A.6 of Treasury Department et al. 2009). This is our measure of U.S. holdings of local currency bonds.

\section{Other Variables}

As explanatory variables in Tables 6, as well as in Figure 3, we use various data series. In Table 5, Yield is the yield-to-maturity in the GBI indexes from J.P Morgan. See J.P Morgan (2006) Appendix B. The other explanatory variables in that table are all from the IMF's IFS database. Inflation is year-over-year inflation in each country. Current account balance is as a percent of GDP. GDP growth is year-over-year real GDP growth. In Figure 3, inflation volatility is computed from ten years of quarterly year-over-year CPI inflation, with the underlying CPI data coming from the IFS database. Legal Rights is 'legal rights for borrowers and lenders' from the World Bank's Doing Business database.

\section{Country Groupings}

The groupings of "advanced economies", or AEs, and "other emerging market and developing countries" (shortened here to emerging market economies or EMEs) follow IMF classification as of April 2006. See http://www.imf.org/external/pubs/ft/weo/2006/01/pdf/statappx.pdf. 


\section{Table 1. Bond Markets}

Data on international bonds are built up from data that underlie two BIS Quarterly Review tables, Table 14B (International Bonds and Notes by Country of Residence) Table 16A (Domestic Debt Securities). Local-currencydenominated debt is the sum of the local currency portion of Table 14B and the long-term debt component from Table 16A. The country groupings follow IMF classifications of "advanced economies" and "other emerging market and developing economies" (shortened to emerging economies) as of April 2006. See http://www.imf.org/external/pubs/ft/weo/2006/01/pdf/statappx.pdf.

\begin{tabular}{|c|c|c|c|c|c|c|c|c|}
\hline & \multicolumn{4}{|c|}{2008} & \multicolumn{2}{|c|}{2006} & \multicolumn{2}{|c|}{2001} \\
\hline & \multirow{2}{*}{$\begin{array}{c}\text { Total } \\
\text { (billion US\$) }\end{array}$} & \multicolumn{3}{|c|}{ Local Currency Denominated } & \multicolumn{4}{|c|}{ Local Currency Denominated } \\
\hline & & (billion US\$) & (\% of GDP) & (\% of total) & (\% of GDP) & (\% of total) & (\% of GDP) & (\% of total) \\
\hline ADVANCED ECONOMIES & 62,581 & 56,537 & 137 & 90 & 130 & 91 & 105 & 93 \\
\hline USA & 24,363 & 23,399 & 162 & 96 & 150 & 96 & 130 & 98 \\
\hline Euro Area & 20,306 & 18,673 & 140 & 92 & 139 & 91 & 96 & 89 \\
\hline Austria & 677 & 573 & 138 & 85 & 133 & 82 & 91 & 74 \\
\hline Belgium & 764 & 749 & 148 & 98 & 129 & 97 & 129 & 97 \\
\hline Finland & 178 & 159 & 58 & 89 & 75 & 89 & 49 & 76 \\
\hline France & 3,429 & 3,178 & 111 & 93 & 112 & 92 & 82 & 91 \\
\hline Germany & 4,143 & 3,740 & 102 & 90 & 118 & 91 & 95 & 92 \\
\hline Greece & 400 & 392 & 111 & 98 & 106 & 97 & 74 & 89 \\
\hline Ireland & 1,150 & 899 & 336 & 78 & 235 & 74 & 46 & 65 \\
\hline Italy & 4,030 & 3,957 & 171 & 98 & 162 & 97 & 119 & 96 \\
\hline Netherlands & 2,419 & 1,994 & 227 & 82 & 241 & 81 & 164 & 74 \\
\hline Portugal & 327 & 325 & 133 & 100 & 110 & 98 & 65 & 90 \\
\hline Spain & 2,789 & 2,706 & 169 & 97 & 156 & 97 & 60 & 93 \\
\hline Other & 17,912 & 14,466 & 106 & 81 & 100 & 82 & 81 & 87 \\
\hline Australia & 683 & 342 & 32 & 50 & 41 & 52 & 30 & 56 \\
\hline Canada & 1,198 & 902 & 60 & 75 & 65 & 77 & 69 & 72 \\
\hline Denmark & 695 & 593 & 174 & 85 & 177 & 85 & 138 & 88 \\
\hline Hong Kong SAR & 72 & 38 & 18 & 53 & 20 & 53 & 15 & 56 \\
\hline Iceland & 66 & 17 & 104 & 27 & 396 & 60 & 91 & 66 \\
\hline Japan & 9,207 & 9,147 & 187 & 99 & 158 & 99 & 110 & 99 \\
\hline New Zealand & 28 & 17 & 13 & 61 & 17 & 57 & 22 & 64 \\
\hline Norway & 261 & 115 & 26 & 44 & 31 & 50 & 27 & 54 \\
\hline Singapore & 123 & 82 & 44 & 67 & 40 & 61 & 37 & 69 \\
\hline South Korea & 872 & 771 & 83 & 88 & 94 & 91 & 85 & 91 \\
\hline Sweden & 508 & 301 & 63 & 59 & 72 & 65 & 56 & 62 \\
\hline Switzerland & 274 & 261 & 52 & 95 & 57 & 95 & 60 & 97 \\
\hline United Kingdom & 3,910 & 1,879 & 70 & 48 & 65 & 52 & 46 & 62 \\
\hline
\end{tabular}


Table 1. Bond Markets, continued

\begin{tabular}{|c|c|c|c|c|c|c|c|c|}
\hline & \multicolumn{4}{|c|}{2008} & \multicolumn{2}{|c|}{2006} & \multicolumn{2}{|c|}{2001} \\
\hline & \multirow{2}{*}{$\begin{array}{c}\text { Total } \\
\text { (billion US\$) }\end{array}$} & \multicolumn{3}{|c|}{ Local Currency Denominated } & \multicolumn{4}{|c|}{ Local Currency Denominated } \\
\hline & & (billion US\$) & (\% of GDP) & (\% of total) & (\% of GDP) & (\% of total) & (\% of GDP) & (\% of total) \\
\hline EMERGING ECONOMIES & 3,922 & 3,336 & 23 & 85 & 24 & 81 & 19 & 70 \\
\hline Europe & 691 & 487 & 14 & 70 & 20 & 72 & 17 & 64 \\
\hline Croatia & 13 & 7 & 10 & 54 & 13 & 49 & 9 & 33 \\
\hline Czech Republic & 69 & 57 & 26 & 83 & 30 & 87 & 14 & 85 \\
\hline Hungary & 97 & 59 & 38 & 61 & 46 & 66 & 28 & 60 \\
\hline Poland & 170 & 127 & 24 & 75 & 33 & 76 & 20 & 86 \\
\hline Russia & 102 & 42 & 3 & 41 & 3 & 41 & 2 & 13 \\
\hline Slovakia & 29 & 23 & 25 & 82 & 28 & 81 & 26 & 68 \\
\hline Turkey & 212 & 171 & 23 & 81 & 33 & 83 & 36 & 78 \\
\hline Latin America & 898 & 643 & 16 & 72 & 19 & 67 & 16 & 51 \\
\hline Argentina & 114 & 56 & 17 & 49 & 30 & 50 & 14 & 29 \\
\hline Brazil & 324 & 256 & 16 & 79 & 15 & 69 & 20 & 59 \\
\hline Chile & 52 & 39 & 23 & 75 & 24 & 71 & 45 & 77 \\
\hline Colombia & 22 & 8 & 3 & 37 & 5 & 36 & 6 & 31 \\
\hline Mexico & 321 & 260 & 24 & 81 & 26 & 79 & 16 & 59 \\
\hline Peru & 24 & 16 & 13 & 67 & 12 & 54 & 12 & 60 \\
\hline Venezuela & 41 & 8 & 2 & 19 & 3 & 19 & 5 & 25 \\
\hline Asia & 2,332 & 2,205 & 31 & 95 & 29 & 93 & 23 & 90 \\
\hline China & 1,468 & 1,451 & 32 & 99 & 28 & 98 & 18 & 95 \\
\hline India & 388 & 358 & 30 & 92 & 32 & 95 & 26 & 97 \\
\hline Indonesia & 67 & 53 & 10 & 80 & 15 & 87 & 27 & 96 \\
\hline Malaysia & 172 & 148 & 67 & 86 & 61 & 79 & 57 & 77 \\
\hline Pakistan & 20 & 17 & 11 & 86 & 15 & 90 & 22 & 96 \\
\hline Philippines & 68 & 36 & 21 & 53 & 27 & 50 & 22 & 48 \\
\hline Thailand & 150 & 142 & 52 & 95 & 51 & 92 & 30 & 81 \\
\hline \multicolumn{9}{|l|}{ Other } \\
\hline South Africa & 99 & 84 & 30 & 84 & 39 & 90 & 32 & 87 \\
\hline
\end{tabular}


Table 2. The Evolution of Maturities in Emerging Market Economy Bonds

The table displays data on the maturity of domestic central government debt outstanding for emerging markets as of 2001, 2006, and 2008. The data, provided by the BIS as an update to BIS (2007), are available at http://www.bis.org/statistics/secstats.htm.

Domestic Central Government Debt Outstanding

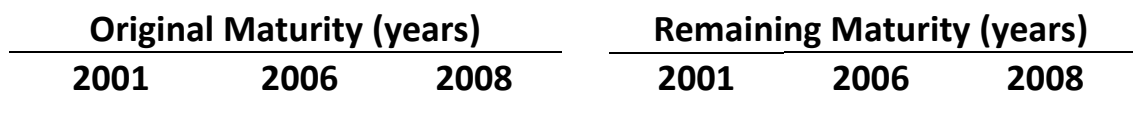

\begin{tabular}{|c|c|c|c|c|c|c|}
\hline Europe & 4.0 & 6.1 & 7.2 & 2.8 & 3.8 & 3.9 \\
\hline \multicolumn{7}{|l|}{ Croatia } \\
\hline Czech Republic & 6.9 & 9.3 & 9.3 & 4.9 & 6.3 & 5.8 \\
\hline Hungary & & & 7.1 & 3.7 & 4.0 & 3.8 \\
\hline Poland & 4.0 & 6.9 & 8.6 & 2.5 & 3.9 & 4.2 \\
\hline Russia & 9.2 & 12.2 & 13.5 & 3.8 & 8.2 & 9.4 \\
\hline \multicolumn{7}{|l|}{ Slovakia } \\
\hline Turkey & 3.2 & 3.5 & 3.9 & 2.7 & 1.9 & 1.9 \\
\hline Latin America & 5.1 & 13.7 & 14.5 & 3.0 & 4.0 & 4.9 \\
\hline Argentina & & 17.0 & 17.9 & & 11.0 & 10.5 \\
\hline Brazil & & & & 3.3 & 2.6 & 3.3 \\
\hline Chile & & 5.6 & 10.2 & & 7.8 & 9.2 \\
\hline Colombia & 5.9 & 7.5 & 8.2 & 4.4 & 3.9 & 4.4 \\
\hline Mexico & & & & 2.0 & 4.3 & 6.5 \\
\hline Peru & 2.3 & 13.9 & 19.4 & 1.8 & 12.2 & 16.6 \\
\hline Venezuela & & & & 2.4 & 11.9 & 14.1 \\
\hline Asia & 10.6 & 13.0 & 11.9 & 4.6 & 7.8 & 7.9 \\
\hline \multicolumn{7}{|l|}{ China } \\
\hline India & 11.0 & 16.9 & 14.9 & & 10.0 & 10.6 \\
\hline Indonesia & & 11.5 & 4.8 & 5.1 & 7.1 & 4.1 \\
\hline Malaysia & & 8.4 & 9.7 & 4.0 & 5.2 & 5.3 \\
\hline \multicolumn{7}{|l|}{ Pakistan } \\
\hline Philippines & 7.7 & 7.9 & 8.1 & 5.0 & 4.7 & 4.9 \\
\hline Thailand & & 8.8 & 10.2 & & 5.4 & 5.8 \\
\hline \multicolumn{7}{|l|}{ Other } \\
\hline South Africa & & 16.8 & 18.3 & & 8.3 & 9.9 \\
\hline
\end{tabular}


Table 3. Monthly US\$ Returns (January 2002 to May 2011)

The table shows returns characteristics of various asset classes. Returns are monthly, in U.S. dollars, and reported for the January 2002 to May 2011 period and separately for the crisis/post-crisis period, from August 2007 to May 2011. Advanced Economies and Emerging Markets consist of countries included in JPMorgan GBI (excluding the US) and JPMorgan GBIEM Broad, respectively. EMBI is of USD-denominated EME bonds.

\begin{tabular}{|c|c|c|c|c|}
\hline & Mean $(\%)$ & Variance & Skewness & $\begin{array}{l}\text { Correlation with } \\
\text { US Govt Bonds }\end{array}$ \\
\hline \multicolumn{5}{|l|}{ January 2002 to May 2011} \\
\hline \multicolumn{5}{|l|}{ EME Local Currency Bonds } \\
\hline Unhedged & 1.01 & 5.50 & -0.54 & 0.16 \\
\hline Hedged & 0.46 & 0.98 & 0.78 & 0.45 \\
\hline \multicolumn{5}{|l|}{ AE Local Currency Bonds } \\
\hline Unhedged & 0.81 & 6.85 & 0.00 & 0.53 \\
\hline Hedged & 0.39 & 0.80 & -0.07 & 0.91 \\
\hline EMBI & 0.91 & 7.36 & -2.45 & 0.24 \\
\hline US Govt Bonds & 0.46 & 2.34 & -0.18 & 1.00 \\
\hline US Corp Bonds & 0.59 & 2.45 & -0.45 & 0.57 \\
\hline \multicolumn{5}{|l|}{ Equities } \\
\hline US & 0.42 & 20.73 & -0.78 & -0.30 \\
\hline Advanced Economies & 0.85 & 28.26 & -0.88 & -0.23 \\
\hline Emerging Markets & 1.66 & 50.85 & -0.87 & -0.20 \\
\hline \multicolumn{5}{|l|}{ August 2007 to May 2011} \\
\hline EME Local Currency Bonds & & & & \\
\hline Unhedged & 0.61 & 9.96 & -0.42 & 0.20 \\
\hline Hedged & 0.36 & 2.05 & 1.35 & 0.50 \\
\hline \multicolumn{5}{|l|}{ AE Local Currency Bonds } \\
\hline Unhedged & 0.79 & 10.06 & -0.14 & 0.66 \\
\hline Hedged & 0.48 & 1.13 & 0.10 & 0.92 \\
\hline EMBI & 0.77 & 16.16 & -2.72 & 0.17 \\
\hline US Govt Bonds & 0.56 & 3.48 & 0.38 & 1.00 \\
\hline US Corp Bonds & 0.79 & 4.74 & -0.83 & 0.28 \\
\hline \multicolumn{5}{|l|}{ Equities } \\
\hline US & -0.52 & 39.29 & -0.61 & -0.10 \\
\hline Advanced Economies & -0.54 & 59.92 & -0.50 & -0.10 \\
\hline Emerging Markets & 0.35 & 108.97 & -0.47 & -0.16 \\
\hline
\end{tabular}




\section{Table 4. U.S. Participation in Local Currency Bond Markets}

The table shows U.S. investors' local currency bond portfolio as of the end of 2001 and 2008. Data are author's calculations using data on U.S. investment from the U.S. Department of the Treasury et al. $(2002,2009)$ and the size of local currency bond markets (mostly from the BIS; see Table 1 for details). $\omega_{U S}$ and $\omega_{\mathrm{mkt}}$ are the weight of the country in US and world market portfolios. The $\omega_{\mathrm{US}}$ to $\omega_{\mathrm{mkt}}$ ratio is a bias measure. It equals one, if the weight of the countries' bonds in US and world market portfolios are identical and less than one, if US investors' underweight the country (relative to its market size).

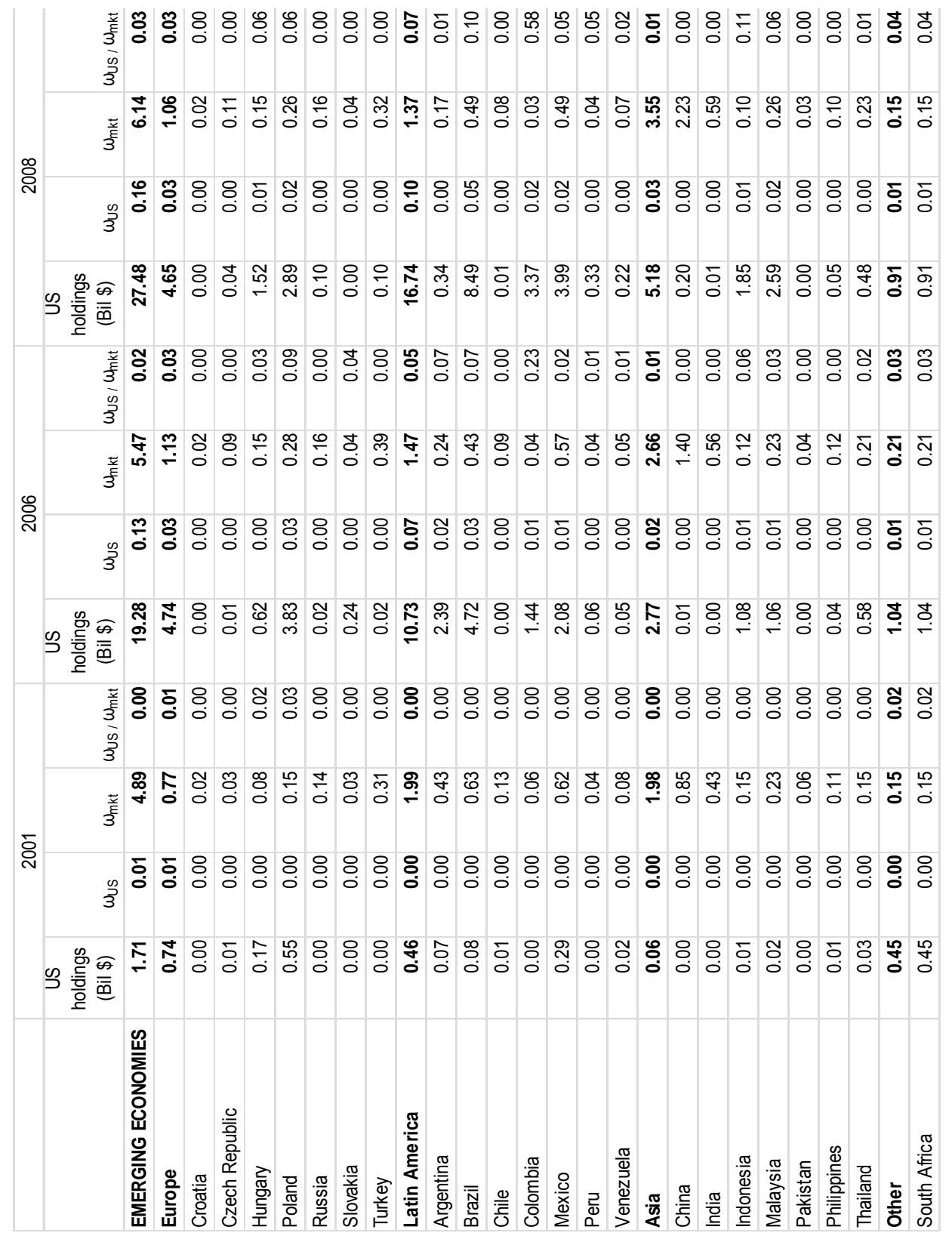




\section{Table 4. U.S. Participation in Local Currency Bond Markets, continued}

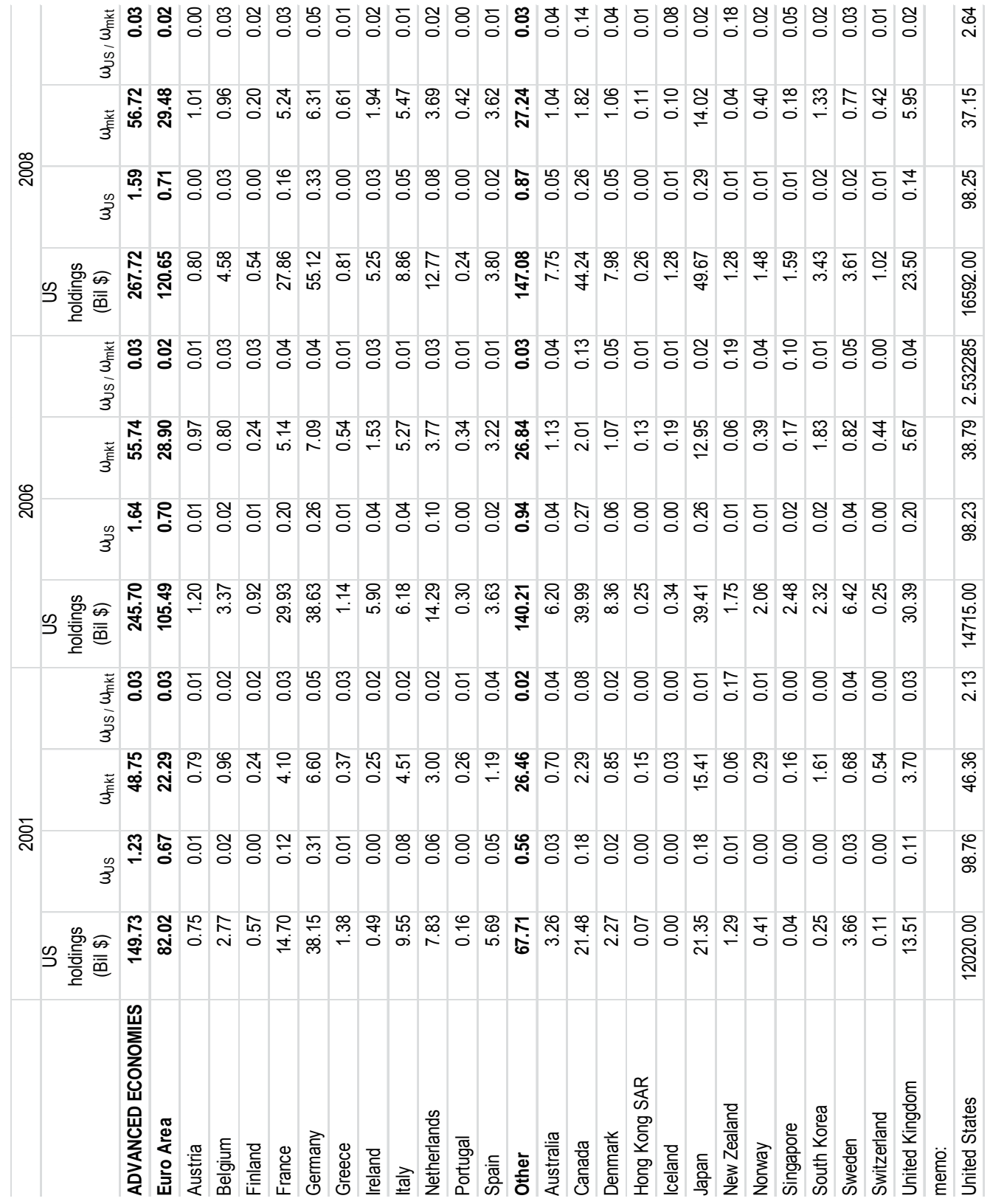




\section{Table 5. Regressions for Expected Mean, Variance, and Skewness}

The table shows dynamic panel regressions of one-year ahead mean, standard deviation, or skewness of unhedged local currency bond returns (in U.S. dollars). Regressions use annual end-of-year data. Yield is the yield on a country's JPMorgan GBI. Inflation is year-over-year inflation in each country. Current account balance is as a percent of GDP. GDP growth is year-over-year real GDP growth. For information on the underlying returns data, see Table 1 and the Data Appendix. ${ }^{* *},{ }^{* *}$, and $*$ denote significance at the $1 \%, 5 \%$, and $10 \%$ levels, respectively.

\begin{tabular}{|l|c|c|c|}
\hline DepVar: & Mean & $\begin{array}{c}\text { Standard } \\
\text { deviation }\end{array}$ & Skewness \\
\hline & & & \\
\hline DepVar & & & $-0.173^{* *}$ \\
\hline Lag 1 & $-0.226^{* * *}$ & $0.084^{*}$ & $0.211^{* * *}$ \\
\hline Lag 2 & & & \\
\hline Yield & & & \\
\hline Lag 1 & $0.005^{* * *}$ & & \\
\hline & -0.000 & & \\
\hline Inflation & & & \\
\hline Lag 1 & 0.000 & & 0.027 \\
\hline & 0.001 & & $-0.081^{* * *}$ \\
\hline Current Account Balance & & & \\
\hline Lag 1 & $0.001^{* * *}$ & & \\
\hline Lag 2 & -0.000 & & 39 \\
\hline & & & $29.9^{* * *}$ \\
\hline GDP Growth & $-0.001^{* *}$ & & $0.251^{* * *}$ \\
\hline Lag 1 & -0.000 & & \\
\hline & & & \\
\hline \# observations & 275 & 520 & \\
\hline \# groups & 41 & & \\
\hline Wald Statistic & $87.8^{* * *}$ & $3.3^{*}$ & \\
\hline $\begin{array}{l}\text { Correlation of predicted and } \\
\text { actual }\end{array}$ & $0.504^{* * *}$ & $0.513^{* * *}$ & \\
\hline
\end{tabular}




\section{Table 6. Regressions of U.S. Holdings of Local Currency Bonds}

The table shows Tobit regressions of the share (from 0 to 1 ) of local currency bonds held by U.S. investors on various investability indicators. Investability ranges from 0 to 1 , with a value of 1 indicating the market is completely open to foreign investment. The expected mean, standard deviation, and skewness of unhedged returns are the predicted values (as of end-2006 or end-2008) from Table 5. Correlations are computed using 3 years of monthly data. For information on the underlying returns data, see Table 1 and the Data Appendix. Regressions include all countries listed in Table 4 except those for which we do not have investability or returns data (Argentina, Croatia, Iceland, Israel, Pakistan, Taiwan, and Venezuela) and Colombia (an extreme outlier). Robust standard errors are in parentheses. ${ }^{* * *},{ }^{* *}$, and ${ }^{*}$ denote significance at the $1 \%, 5 \%$, and $10 \%$ levels, respectively.

2008 Regressions

\begin{tabular}{|c|c|c|c|c|c|c|c|}
\hline Investability Measure: & Aggregate & CA Open & Liq Eff & Reg_CR & Mkt St & Tax & Dominv \\
\hline Investability & $\begin{array}{l}0.0510^{* *} \\
(0.0202)\end{array}$ & $\begin{array}{c}0.0884^{*} \\
(0.0495)\end{array}$ & $\begin{array}{c}0.202^{* *} \\
(0.0823)\end{array}$ & $\begin{array}{l}0.261^{* *} \\
(0.118)\end{array}$ & $\begin{array}{c}0.300^{* * *} \\
(0.101)\end{array}$ & $\begin{array}{l}0.0985 \\
(0.127)\end{array}$ & $\begin{array}{c}0.382^{* * *} \\
(0.137)\end{array}$ \\
\hline exp_mean08 & $\begin{array}{c}-0.0885 \\
(0.232)\end{array}$ & $\begin{array}{c}-0.0546 \\
(0.251)\end{array}$ & $\begin{array}{c}-0.205 \\
(0.275)\end{array}$ & $\begin{array}{l}0.0170 \\
(0.238)\end{array}$ & $\begin{array}{l}-0.191 \\
(0.208)\end{array}$ & $\begin{array}{c}-0.106 \\
(0.286)\end{array}$ & $\begin{array}{r}-0.0201 \\
(0.196)\end{array}$ \\
\hline exp_skew08 & $\begin{array}{c}0.0161 \\
(0.0124)\end{array}$ & $\begin{array}{c}0.0155 \\
(0.0132)\end{array}$ & $\begin{array}{c}0.0197 \\
(0.0134)\end{array}$ & $\begin{array}{c}0.0146 \\
(0.0121)\end{array}$ & $\begin{array}{c}0.0221^{*} \\
(0.0123)\end{array}$ & $\begin{array}{c}0.0184 \\
(0.0135)\end{array}$ & $\begin{array}{c}0.0186 \\
(0.0121)\end{array}$ \\
\hline corr3yr08 & $\begin{array}{c}-0.0360^{* *} \\
(0.0173)\end{array}$ & $\begin{array}{c}-0.0237 \\
(0.0150)\end{array}$ & $\begin{array}{c}-0.0428^{* *} \\
(0.0202)\end{array}$ & $\begin{array}{l}-0.0249^{*} \\
(0.0146)\end{array}$ & $\begin{array}{c}-0.0415^{\star *} \\
(0.0162)\end{array}$ & $\begin{array}{l}-0.0194 \\
(0.0142)\end{array}$ & $\begin{array}{c}-0.0302^{* *} \\
(0.0142)\end{array}$ \\
\hline Investability Measure: & Aggregate & CA Open & Liq Eff & Reg_CR & Mkt St & Tax & Dominv \\
\hline Investability & $\begin{array}{c}0.0518^{* * *} \\
(0.0184)\end{array}$ & $\begin{array}{c}0.111^{* *} \\
(0.0427)\end{array}$ & $\begin{array}{l}0.219^{* *} \\
(0.104)\end{array}$ & $\begin{array}{l}0.278^{\star *} \\
(0.114)\end{array}$ & $\begin{array}{c}0.201^{* *} \\
(0.0822)\end{array}$ & $\begin{array}{l}0.210^{* * *} \\
(0.0676)\end{array}$ & $\begin{array}{l}0.227^{* *} \\
(0.110)\end{array}$ \\
\hline exp_mean06 & $\begin{array}{c}0.356^{\star} \\
(0.208)\end{array}$ & $\begin{array}{l}0.447^{* *} \\
(0.218)\end{array}$ & $\begin{array}{c}0.288 \\
(0.218)\end{array}$ & $\begin{array}{l}0.460^{* *} \\
(0.224)\end{array}$ & $\begin{array}{c}0.187 \\
(0.210)\end{array}$ & $\begin{array}{c}0.415^{*} \\
(0.230)\end{array}$ & $\begin{array}{c}0.229 \\
(0.238)\end{array}$ \\
\hline exp_sd06 & $\begin{array}{c}5.801 \\
(4.264)\end{array}$ & $\begin{array}{c}4.642 \\
(4.113)\end{array}$ & $\begin{array}{c}7.203 \\
(4.919)\end{array}$ & $\begin{array}{c}4.865 \\
(4.144)\end{array}$ & $\begin{array}{c}6.418 \\
(4.468)\end{array}$ & $\begin{array}{c}4.551 \\
(4.351)\end{array}$ & $\begin{array}{c}5.476 \\
(4.313)\end{array}$ \\
\hline
\end{tabular}




\section{Figure 1. Some Determinants of Local Bond Market Development}

Two fundamental factors of local currency bond market development are inflation volatility (shown as the volatility of 10 years of quarterly year-over-year inflation) and legal rights for borrowers and lenders (from the World Bank's Doing Business reports). As in 2001 data analyzed in Burger and Warnock (2006), in 2008 countries with less inflation volatility and stronger legal rights had larger local currency bond markets (expressed as a percent of GDP).
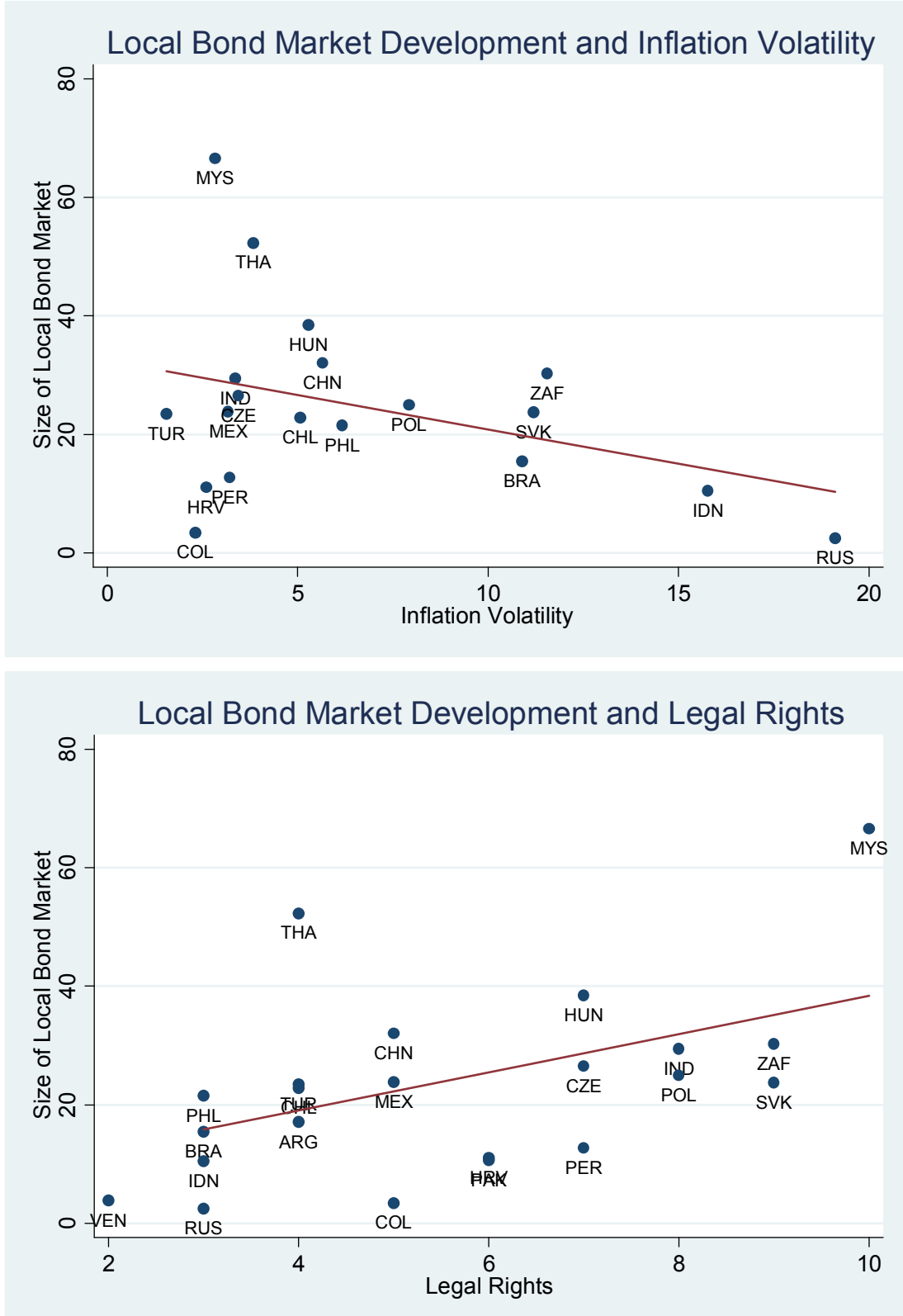


\section{Figure 2. Efficient Frontiers for Bond Portfolios}

Each frontier includes a range of portfolios varying from 100\% U.S. bonds (the common point in each line) to $100 \%$ foreign bonds. The figure includes three definitions for the rest-of-world (ROW) portfolio: (1) an unhedged portfolio of 80 percent $\mathrm{AE}$ and 20 percent EME bonds (the steep, blue line), (2) a hedged portfolio of 80 percent $\mathrm{AE}$ and 20 percent EME bonds (the downward-sloping red line), and (3) a 50-50 combination of (1) and (2) (the line in the middle). Returns data are from January 2002 to May 2011. The vertical axis is monthly return (in percent); the horizontal axis is standard deviation of the monthly returns.

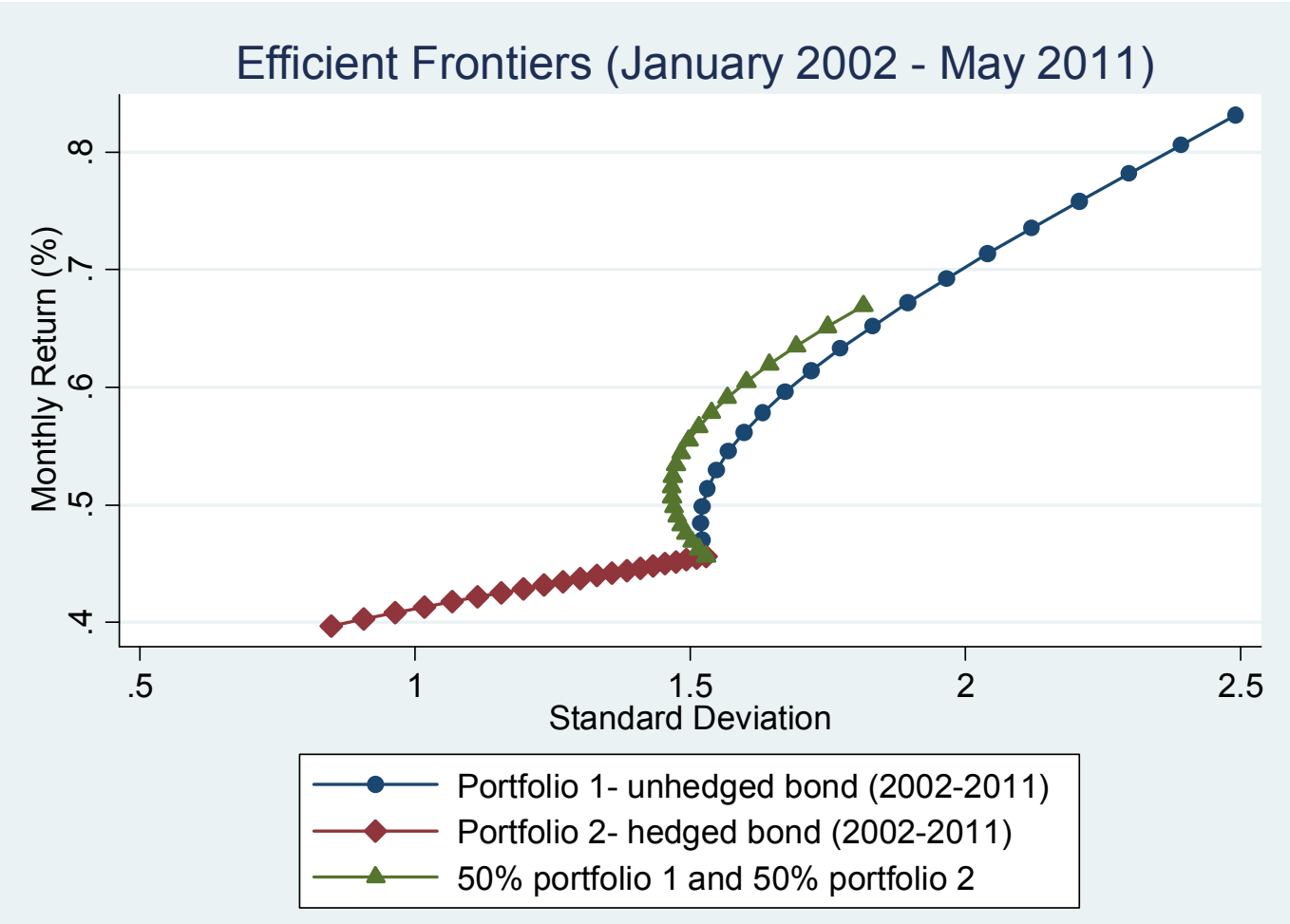




\section{Figure 3. Efficient Frontiers for Broad Portfolios}

Each frontier includes a range of broad portfolios varying from $100 \%$ U.S. (the common point in each line) to $100 \%$ foreign. For weights for the U.S. portion we chose 2006 estimates from the Federal Reserve's Flow of Funds accounts: $62 \%$ equities, $38 \%$ bonds, of which $43 \%$ government and $57 \%$ corporate. For the rest-of-world (ROW) portion, weights, which come from Treasury Department surveys as described in Table 4 and the Data Appendix, are $77 \%$ equity (of which $79 \% \mathrm{AE}$ and $21 \% \mathrm{EME}$ ) and $23 \%$ bond ( $89 \% \mathrm{AE}, 9 \%$ USD-denominated EME, 2\% local currency EME). The figure includes three definitions for the ROW bond portfolio: (1) unhedged (the steepest, blue line), (2) hedged (the red line), and (3) a 50-50 combination of (1) and (2) (the line in the middle). In the bottom graph we ramp up the local currency EME bond weight by increasing the overall bond weight in the ROW portfolio to $59.4 \%$ and the local currency EME portion of that to $20 \%$. Returns data are from January 2002 to May 2011. The vertical axes are monthly return (in percent); the horizontal axes are standard deviation of the monthly returns.
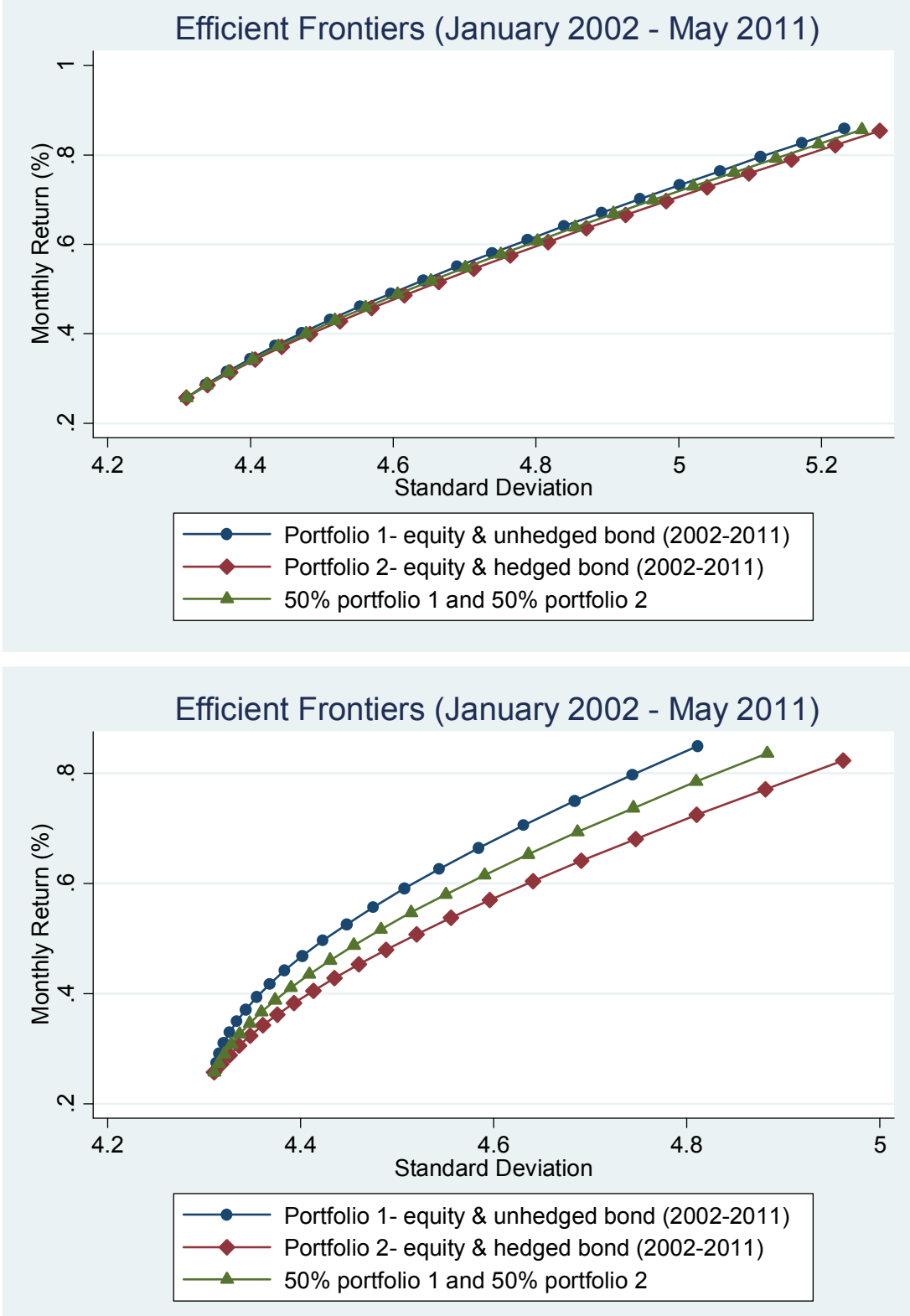


\section{Figure 4. U.S. Investment and Investability Index, GEMX Countries}

U.S. Holdings is the portion of the country's outstanding local currency bonds that is held by U.S. investors; bond holdings data are as of end-2006 from U.S. Department of the Treasury et al. (2007). Investability for GEMX countries is from CRISIL (2008) and is comprised of the following six components: capital controls, market liquidity and efficiency, regulatory quality and creditor rights, market infrastructure, taxation on bonds, and the size of the local institutional investor base. The $\mathrm{R}^{2}$ of the regression line is 0.24 . A graph for 2008 (not shown) is similar if one extreme outlier (Venezuela) is omitted.

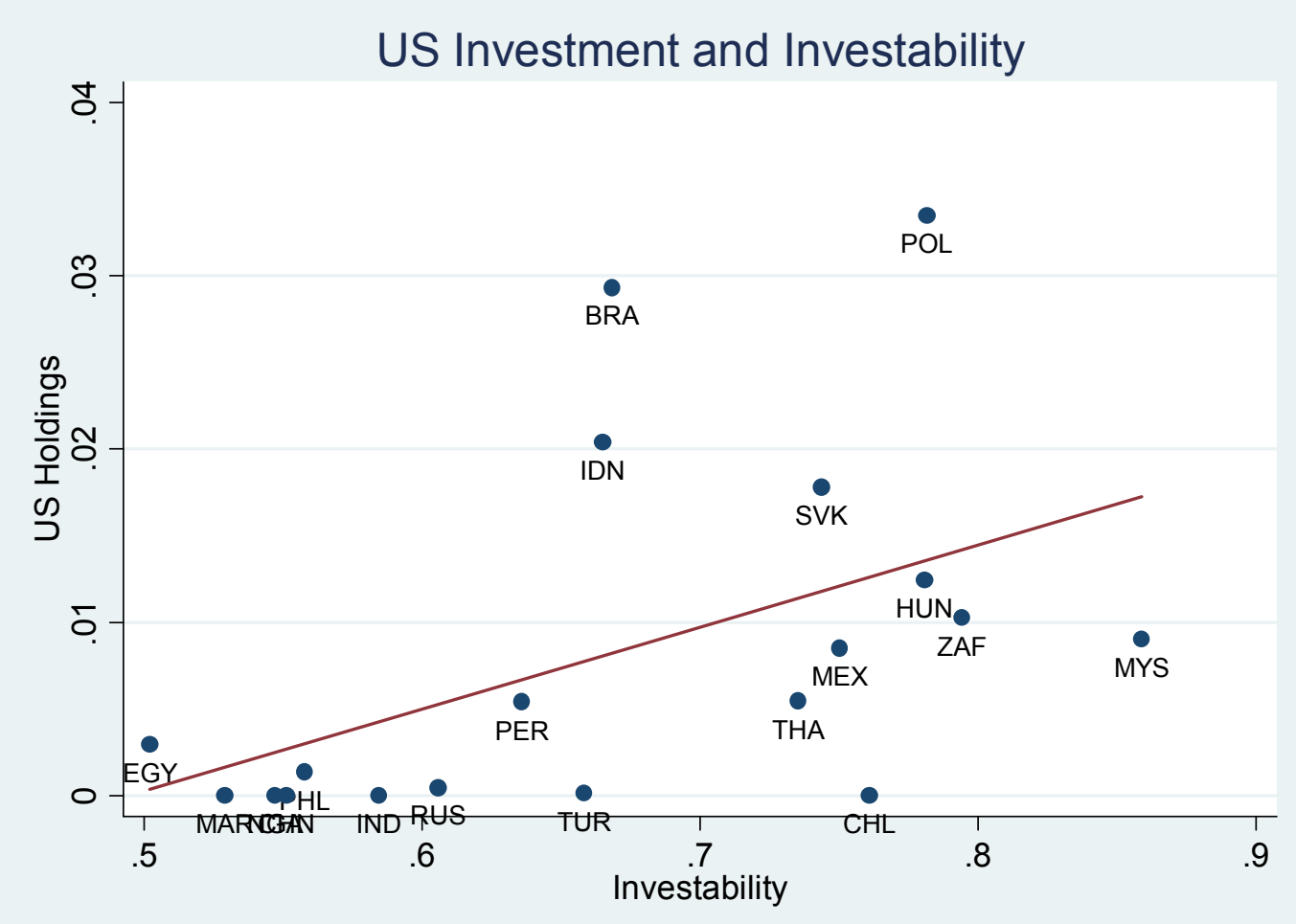

